\title{
EVALUATION OF PASTURE QUALITY UNDER NEW ZEALAND CONDITIONS
}

\author{
M. J. Ulyatt
}

Applied Biochemistry Division, DSIR, Palmerston North

\section{Summary}

Pasture quality has been defined as a function of both intake and nutritive value. Results of New Zealand work on the quality of individual pasture species is collated. All grasses studied were of higher quality than perennial ryegrass and the legumes were higher again than the grasses. Possible reasons for these differences are considered. The role of digestibility in defining pasture quality has been examined and it was concluded that digestibility is a useful index for low and medium quality herbage, but is of limited use for high quality herbage. Consideration is given to the choice of a suitable index for high quality herbages.

THE ultimate criterion of pasture quality under New Zealand conditions must- be the production of the grazing ruminant. Numerous methods of forage evalution have been devised (see Raymond (1969) for a comprehensive review) but the preferred method for a grazing ecosystem is to measure animal production while the pasture is being grazed. Under these conditions, the pasture should always be in a vegetative state and feed availability should not limit animal production.

Rather loose terminology has been used in this field and the terms nutritive value, pasture quality, and feeding value are commonly used but rarely defined. Animal production 'depends on the amount of nutrients that the animal can utilize from the food consumed. In this paper the following definition will be used:

Nutrients utilized by animal $=$ Intake (I) $\mathrm{X}$ Nutritive value (NV)

In this sense, NV is a measure of food utilization per unit of intake and can be regarded as a concentration factor. The nutrients utilized by an animal can be partitioned into those required for maintenance and those required for the production of meat, wool or milk. It is difficult to make an accurate estimate of maintenance with grazing animals but production can be measured in terms of liveweight gain (LWG), wool growth or milk yield. If we assume that maintenance requirements are not affected by the pasture type fed, then pasture quality can be assessed in terms of animal production. 
Pasture quality $=$ Animal production $=f(\mathrm{I} \quad \mathrm{X} \quad \mathrm{NV})$

In this way pasture quality is estimated as response per animal and is dependent on both I and NV. The response in animal production will depend on the type of animal, its physiological state, and the environment to which it is subjected. We have standardized on wether sheep of approximately $30 \mathrm{~kg}$ initial liveweight and we measure LWG as our criterion of pasture quality.

\section{RESULTS FROM NEW ZEALAND GRAZING EXPERIMENTS}

When a field approach is adopted to study pasture quality, only a few comparisons can be made at any time. For this reason, most of the work in this country has centred on our main improved species. The results of a number of experiments, where pasture quality has been assessed as sheep liveweight gain, have been collated in Table 1. The

TABLE 1: THE RELATIVE QUALITY OF NEW ZEALAND PASTURE SPECIES UNDER GRAZING CONDITIONS

\begin{tabular}{|c|c|c|c|c|}
\hline & $\begin{array}{l}\text { No. of L } \\
\text { Experiments }\end{array}$ & $\begin{array}{l}\text { Relative } \\
\text { iveweight } \\
\text { Gain }\end{array}$ & $\begin{array}{c}\text { Range in } \\
\text { Liveweight } \\
\text { Gain } \\
\text { (g/day) }\end{array}$ & References* \\
\hline $\begin{array}{l}\text { Perennial ryegrass } \\
\text { Manawa ryegrass } \\
\text { Ariki ryegrass } \\
\text { Italian ryegrass } \\
\text { Timothy } \\
\text { White clover } \\
\text { Lucerne }\end{array}$ & $\begin{array}{r}12 \\
11 \\
2 \\
1 \\
5 \\
7 \\
5\end{array}$ & $\begin{array}{l}100 \\
148 \\
111 \\
160 \\
129 \\
186 \\
170\end{array}$ & $\begin{array}{c}23-227 \\
45-270 \\
86-150 \\
141 \\
127-168 \\
168-331 \\
154-291\end{array}$ & $\begin{array}{l}2,3,4,5,7 \\
2,3,4,57 \\
5 \\
5 \\
3,4 \\
3,4,7 \\
3,4\end{array}$ \\
\hline \multicolumn{5}{|l|}{$\begin{array}{l}\text { Autumn comparison in } \\
\text { Gisborne district }\end{array}$} \\
\hline $\begin{array}{l}\text { Perennial ryegrass } \\
\text { White clover }\end{array}$ & $\begin{array}{l}6 \\
6\end{array}$ & $\begin{array}{r}100 \\
412\end{array}$ & $\begin{array}{c}18-86 \\
127-195\end{array}$ & $\begin{array}{l}1,6 \\
1,6\end{array}$ \\
\hline
\end{tabular}

*References: 1. Hight and Sinclair (1965). 2, Johns et al. (1963). 3. McLean et al. (1962). 4. McLean et al. (1965). 5. Rae et al. (1964). 6. Sinclair et al. (1956). 7. Ulyatt (unpublished).

data are expressed relative to perennial ryegrass and the ranges in liveweight gain have also been included. As the results are from a number of environments and years, they cannot be interpreted too rigidly; however, several generalisations can be made (see also Butler et al., 1968) : 
(1) Perennial ryegrass, our major improved species, is of lower quality than the other species tested.

(2) The more annual ryegrasses are of higher quality than the more perennial varieties.

(3) The legumes, white clover and lucerne are of higher quality than any of the grasses studied.

The results from Gisborne in the autumn are kept separate to indicate seasonal and climatic variation. The high relative gains on white clover were not due to high rates of gain on the clover, but to poor rates on the pert $n$ nial ryegrass.

Because of seasonal and plant physiological factors, it is not possible to keep our pastures in a vegetative state throughout the year. As a consequence, there are seasonal variations in pasture quality. Hutton (1962) showed that the apparent digestibility of the energy of a mixed pasture declined from about $75 \%$ in early spring to $63 \%$ in late summer and then rose again. A similar pattern has been shown for individual grass species in England by Minson et al. (1964) and it seems that as a species approaches flowering and the ratio of leaf to stem declines so the quality declines. However, the digestibility of improved pastures in New Zealand is only likely to be below $70 \%$ for a few dry summer months.

\section{THE COMPONENTS OF PASTURE QUALITY}

\section{(1) INTAKE}

Although intake is a major component in determining animal performance, its role in the grazing system has proved difficult to assess. This is because there is great variation between animals in food intake. Ulyatt (unpublished) has calculated that approximately 10 plots per treatment stocked with two sheep per plot are required to detect intake differences between treatments of approximately 10\%. No consistent differences in intake were observed by Ulyatt (unpublished) or Grimes et al. (1967) with grazing sheep, or by Rattray and Joyce (1969) with pen-fed sheep. In contrast, McLean et al. (1962) estimated that grazing sheep consumed considerably more white clover and lucerne than perennial or Manawa ryegrasses, while Joyce and Newth (1967) also found that sheep ate more white clover than perennial ryegrass in an indoor trial. Ulyatt (unpublished) attempted to partition the differences in liveweight gain between intake and NV mathematically and 
concluded that they contribute in approximately equal amounts. Thus it seems that intake cannot alone account for all the variation observed in liveweight gain.

\section{(2) Nutritive Value}

Many variables can influence NV. It must depend on food composition and theoretically it should be possible to describe NV chemically. Numerous attempts have been made to do this (Raymond, 1969), but no solution clearly satisfactory in all circumstances has been found. Most of the work done in this country has concentrated on our major improved species, perennial ryegrass (P), Manawa ryegrass $(\mathrm{S})$, and white clover $(\mathrm{C})$, and the rest of the discussion will be restricted to this work. Some of these results are shown in Table 2. In the experiments from which they are drawn, there were. large differences between species in liveweight gain and in energy retained per gram of organic matter intake, which is a measure of NV. The intakes were not significantly different, although the intake of P was approximately $20 \%$ lower than S or C.

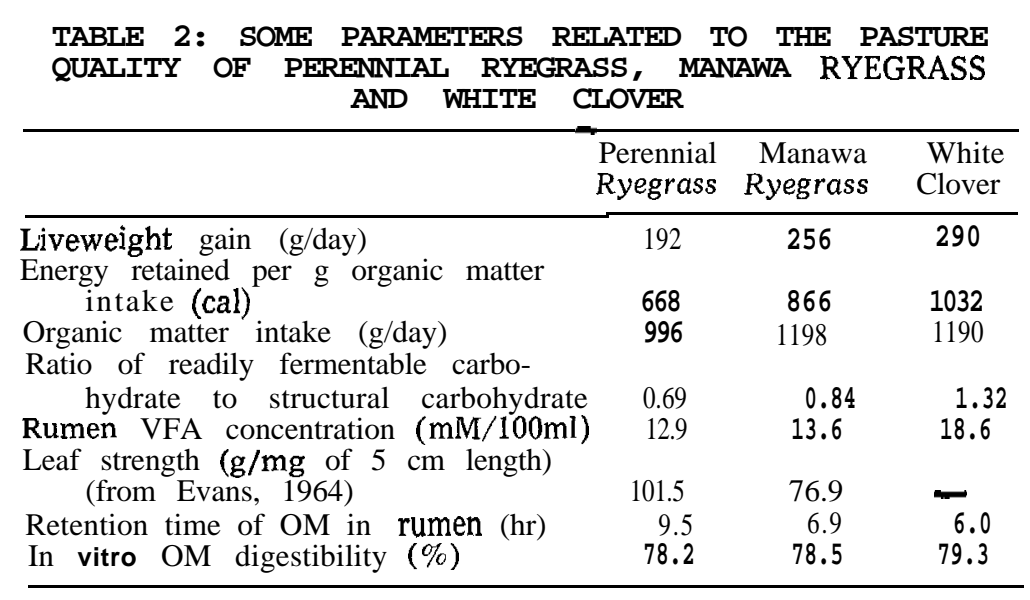

Some progress has been made in defining the causes of these differences. Bailey (1964) noted that the more annual ryegrasses contained more soluble sugars and less cellulose than the more perennial ryegrasses. This can be expressed as the ratio of readily fermentable to structural carbohydrate and, as is seen in Table 2, C > S > P. A high ratio should lead to rapid fermentation in the rumen and, in fact, the volatile fatty acid concentration in the rumen 
is higher for $\mathrm{C}$ than the ryegrasses. The significance of this is that volatile fatty acids can account for up to $80 \%$ of the net energy requirements of the ruminant (Blaxter, 1962). Evans (1964) has demonstrated structural differences between the ryegrasses and Table 2 shows that the leaves of $\mathrm{P}$ are of higher tensile strength than those of $\mathrm{S}$. Such differences in physical composition could influence the rate of breakdown of food in the rumen and Table 2 shows that organic matter of $\mathrm{P}$ is retained in the rumen much longer than $\mathrm{S}$ or $\mathrm{C}$. The data presented in Table 2 illustrate some of the many factors that are thought to contribute to differences in the nutritive value of temperate species. They emphasize the central role of rate of breakdown in the rumen.

(3) The Rote of Digestibility

The apparent digestibility of a forage has traditionally been used as a measure of its quality. Digestibility is a useful parameter but often too much is expected of it. Digestibility only measures the difference between the food consumed and faecal output, and it tells nothing of the processes of digestion or of the efficiency of endproduct utilization by the animal. Digestibility is an effect of the processes of digestion, not a cause. For feeds below approximately $70 \%$ digestibility there seems to be a good relationship between digestibility and NV. In this range there is also a good relationship between intake and digestibility (Blaxter et al., 1961). This probably means that, for low and medium quality forages, intake is the main determinant of animal performance (Crampton et al., 1960; Ingalls et al., 1965). It is likely that the animal is unable to eat enough of this type of food to satisfy its demands -that is, the bulk of non-digestible components in the feed limit nutrient intake and thus animal performance.

Relationships between digestibility, intake and NV appear to break down, however, at digestibilities greater than $70 \%$ (Minson et al., 1964; Osbourn et al., 1966; Miles et al., 1969). This is, of course, the region where the majority of our pasture species lie. A good example can be seen in Table 2, where there were significant differences between $\mathrm{P}, \mathrm{S}$ and $\mathrm{C}$ in $\mathrm{NV}$ yet no differences in in vitro digestibility. It appears that; at approximately $70 \%$ digestibility, animal performance ceases to be limited by nutrient intake. Additional production then depends on the manner in which the end-products of digestion are 
utilized. Digestibility tells us nothing about the site of digestion of food and evidence is accumulating which suggests that this is important in determining the efficiency of food utilization. For example, it has been demonstrated (Blaxter, 1962) that protein is $44 \%$ more efficiently utilized when digested in the duodenum rather than the rumen. This means that the more plant protein that can escape rumen digestion, or the more microbial protein that is synthesized in the rumen, the greater will be the efficiency of utilization of feed protein.

\section{CHOICE OF AN INDEX OF PASTURE QUALITY}

Assessment of pasture quality by field trials is very slow. However, there are many instances, such as in the initial stages of a plant breeding programme, or in farm advisory work, where a simple index of quality would be of great value. Such an index must be relatively easy to measure. To date, the in vitro digestibility technique of Tilley and Terry (1963) is probably the most satisfactory, provided that the limitations of digestibility per se as discussed above are recognized. Certainly for feeds lower than $70 \%$ digestibility, the in vitro technique seems satisfactory and it has the advantage that, at this level, digestibility is well related to both intake and NV. These points are well illustrated if reference is made to recent work where in vitro digestibility was used as a selection index in a plant breeding programme. Burton et al. (1967) studied the in vitro digestibility of cultivars of Bermuda grass. Their parent material was of low digestibility and they indicated that considerable improvement in digestibility could be achieved by selection. On the other hand, Cooper et al. (1962) found a significant heritability of in vitro digestibility between cocksfoot genotypes but not between perennial ryegrass genotypes. They considered that there was more margin for improvement of NV in cocksfoot which was of lower digestibility than the perennial ryegrass.

The problem of finding a suitable index for high quality pastures is yet to be resolved and this is one of the aims of our work. Techniques that measure the rate of reduction of particle size in the rumen such as those of Chenost (1966) or Troelson and Bigsby (1964) might prove suitable. The leaf strength measurement of Evans (1964) seems to be useful for ryegrasses but cannot be used for clovers. Another possibility is the ratio of readily fermentable to structural carbohydrate. Work is currently being initiated to study some of these possibilities. 


\section{REFERENCES}

Bailey, R. W., 1964: N.Z. Jl agric. Res., 7: 496-507.

Blaxter, K. L., 1962: The Energy Metabolism of Ruminants. Hutchinson, London.

Blaxter, K. L.; Wainman, F. W.; Wilson, R. S., 1961: Anim. Prod. 3: 51-61.

Burton, G. W.; Hart, R. H.; Lowrey, R. S., 1967: Crop Sci., 7: 329-32. Butler, G. W.; Rae, A. L.; Bailey, R. W., 1968: N.Z. agric. Sci., 3: 8-12.

Chenost, M, 1966: Proc. 10th int. Grassld Congr.: 406-11.

Cooper, J. P.; Tilley, J. M. A.; Raymond, W. F.; Terry, R. A., 1962: Nature (Lond.), 195: 1276-7.

Crampton, E. W.; Donefer, E.; Lloyd, L. E., 1960: J. Anim. Sci., 19: 538.

Evans, P. S., 1964: N.Z. Il agric. Res., 7: 508-13.

Grimes, R. C.; Watkin, B. R.; Gallagher, J. R., 1967: J. agric. Sci., Carnb., 68: 11-21.

Hight, G. K.; Sinclair, D. P., 1965: N.Z. Jl agric. Res., 8: 1079-86.

Hutton, J. B., 1962: Ibid., 5: 409-24.

Ingalls, J. R.; Thomas, J. W.; Benne, E. J.; Tesar, M., 1965: J. Anim. Sci., 24: 1159-64

Johns, A. T.; Ulyatt, M. J.; Glenday, A. C., 1963 : J. agric. Sci., Camb., 61: 201-6.

Joyce, J. P.; Newth, R. P., 1967: Proc. N.Z. Soc. Anim. Prod., 27: 166-80

McLean, J. W.; Thomson, G. G.; Iversen, C. E.; Jagusch, K. T.; Lawson, B. M., 1962: Proc. N.Z. Grassld Ass., 24: 57-70.

McLean, J. W.; Thomson, G. G.; Jagusch, K. T.; Lawson, B. M., 1965: Proc. Ruakura Fmrs' Conf. Week: 34-42.

Miles, D. G.; Walters, R. J. K.: Evans, E. M., 1969: Anim. Prod., 11: 19-28.

Minson, D. J.; Harris, C. E.; Raymond, W. F.; Milford, R., 1964 J. Br. Grassld Soc., 19: 298-305.

Osboum, D. F.; Thomson, D. J.; Terry, R. A., 1966: Proc. 10th int Grassld Congr.: 363-7.

Rae, A. L.; Brougham, R. W.; Barton, R. A., 1964: N.Z Jl agric Res., 7: 491-5.

Rattray, P. V.; Joyce, J. P., 1969: Proc. N.Z. Soc. Anim. Prod., 29: $102-13$.

Raymond, W. F., 1969: Adv. Agron., 21: 1-108.

Sinclair, D. P.; Clarke, A. E.; Filmer, D. B., 1956: Proc. N.Z. Soc. Anim. Prod., 16: 23-32.

Tilley, J. M. A.; Terry, R. A., 1963: J. Br. Grassld Soc., 18: 104-11.

Troelson, J. E.; Bigsby, F W., 1964: J. Anim. Sci., 23: 1139-42.

Wilson, D., 1965: J. agric. Sci., Camb., 65: 285-92. 


\section{DISCUSSION}

Asked by Marten (U.S.A.) how grazing pressure was controlled in his comparison of ryegrass and white clover, Ulyatt replied that it was done in two ways: (a) with non-experimental sheep, and (b) by use of the forage harvester to control clumps.

Barnes (U.S.A.) suggested the use of the pepsin organic matter solubility technique, but Ulyatt considered this was not yet positively related to intake. Taylor had measured the rate of release of soluble components but had not yet tied it in with animal data. Here Woodford (U.K.) commented that there was a direct correlation between pepsin digested material and digested fibre. One must look at the digested portion rather than at the whole feed.

Campbell suggested that, if feed was non-limiting, animals would be able to select and thus leave indigestible material behind. This might have led to invalid conclusions on the nutritive value of the whole plant as measured by the technique described. Ulyatt disagreed, saying that there had -been a reasonable grazing pressure of up to 14 sheep/acre in spring. In practice, pure pastures would not be grazed in New Zealand as it would be a grass/legume sward. From the animal production viewpoint, one should allow the animal to select what it wanted as the interest at that stage was in production per animal.

Asked by Browne (Ireland) what differences he would expect with beef animals and with dairy cows, Ulyatt replied that he had not worked with either. However, he would expect beef animals to behave similarly. Wilson, at Massey University, had generally obtained the same differences, but rather less clear-cut. The dairy cow could utilize body reserves which could mask intake.

To a question from Marten (U.S.A.) as to whether indoor trials were done at ad libitum intake. Ulyatt replied that he had used both ad lib. and restricted intakes for indoor experiments. Despite limitations, he had decided to remain with outdoor trials.

Joyce inquired whether species would rank the same indoors and outdoors. Ulyatt thought they would be quantitatively similar but, to ascertain what contribution intake made, measurements must be made outdoors. 